\title{
Catherine Martin, Le premier testament de Marie de Gournay
}

\section{Filippo Fonio}

\section{(2) OpenEdition \\ 1 Journals}

\section{Edizione digitale}

URL: http://journals.openedition.org/studifrancesi/27472

DOI: $10.4000 /$ studifrancesi.27472

ISSN: 2421-5856

Editore

Rosenberg \& Sellier

\section{Edizione cartacea}

Data di pubblicazione: 31 décembre 2006

Paginazione: 594

ISSN: 0039-2944

\section{Notizia bibliografica digitale}

Filippo Fonio, « Catherine Martin, Le premier testament de Marie de Gournay », Studi Francesi [Online], 150 (L | III) | 2006, online dal 30 novembre 2015, consultato il 08 novembre 2020. URL : http:// journals.openedition.org/studifrancesi/27472 ; DOI : https://doi.org/10.4000/studifrancesi.27472

Questo documento è stato generato automaticamente il 8 novembre 2020.

\section{(c) (i) (9)}

Studi Francesi è distribuita con Licenza Creative Commons Attribuzione - Non commerciale - Non opere derivate 4.0 Internazionale. 


\title{
Catherine Martin, Le premier testament de Marie de Gournay
}

\author{
Filippo Fonio
}

\section{NOTIZIA}

CATHERINE MARTIN, Le premier testament de Marie de Gournay, «Bibliothèque d'Humanisme et Renaissance», LXVII, 3 (2005), pp. 653-658.

1 Steso il 28 novembre 1596, questo primo testamento di Marie de Gournay (1565-1645), di cui la studiosa propone la trascrizione, sarà seguito a distanza di parecchi anni da altri due, rispettivamente del 1642 e 1644, e da due codicilli del marzo 1645, poco prima della morte. Ancora nel ricordo della scomparsa del maestro e amico Montaigne, e sull'onda di una situazione economica familiare non facile, il primo testamento di Marie de Gournay è lontano dai canoni degli atti del tempo, rispetto ai quali attenua molto la componente devozionale, costituendo in pratica un documento in cui la firmataria dispone dell'amministrazione dei propri beni e attesta la propria riconoscenza nei confronti degli eredi di Montaigne. 